Published in final edited form as:

J Carbohydr Chem. 2013 ; 32(5-6): 392-409. doi:10.1080/07328303.2013.815196.

\title{
Synthesis of $\mathrm{N}$-acetyl Glucosamine Analogs as Inhibitors for Hyaluronan Biosynthesis
}

\author{
Gilbert Wasonga ${ }^{1}$, Yota Tatara ${ }^{2}$, Ikuko Kakizaki ${ }^{2}$, and Xuefei Huang ${ }^{1}$ \\ ${ }^{1}$ Department of Chemistry, Michigan State University, East Lansing, MI 48824, USA \\ ${ }^{2}$ Department of Glycotechnology, Center for Advanced Medical Research, Hirosaki University \\ Graduate School of Medicine, Hirosaki 036-8224, Japan
}

\begin{abstract}
Elevated hyaluronan expression is a hallmark of many types of cancer. Therefore, inhibition of hyaluronan biosynthesis can potentially slow the growth of tumor cells. Herein, we explore a chain termination strategy to reduce hyaluronan synthesis by tumor cells. Several analogs of glucosamine were prepared, which contained modifications at the C-3 positions. These analogs can possibly cap the nonreducing end of a growing hyaluronan chain, thus lowering the amount of hyaluronan synthesized. Upon incubation with pancreatic cancer cells, a fluorine-containing glucosamine analog was found to exhibit significant inhibitory activities of hyaluronan synthesis. Furthermore, it drastically reduced the proliferation of cancer cells.
\end{abstract}

\section{Keywords}

Biosynthesis; Chain terminator; Hyaluronan; Inhibitor; Salvage pathway

\section{Introduction}

Hyaluronan (HA), a member of the glycosaminoglycan family, is composed of repeating disaccharides of $\beta-1,3-N$-acetyl-glucosamine- $\beta-1,4$-glucuronic acid. ${ }^{[1]}$ HA plays important roles in tumor development, metastasis, and drug resistance. ${ }^{[2-4]}$ HA expression is elevated in a variety of tumors, ${ }^{[5]}$ with the high levels of HA shown to have prognostic values for various cancers, such as non-small cell lung, bladder, gastric, and prostate cancer. ${ }^{[6-9]}$ Therefore, inhibition of HA biosynthesis can be an interesting approach toward cancer treatment.

HA biosynthesis is mediated by HA synthases, ${ }^{[10]}$ which use UDP- $\alpha-N$-acetyl-Dglucosamine (UDP-GlcNAc) and UDP- $\alpha$-D-glucuronate (UDP-GlcA) as substrates to sequentially transfer GlcNAc and GlcA to the nonreducing end of a growing HA chain. 4Methylumbelliferone (4-MU) was found to be an HA synthesis inhibitor, ${ }^{[11]}$ which functions by suppressing the expression of HA synthases. ${ }^{[12]}$ 4-MU can also serve as an acceptor for

Address correspondence to Xuefei Huang, Department of Chemistry, Chemistry Building, Room 426, 578 S. Shaw Lane, Michigan State University, East Lansing, Michigan, 48824 USA. xuefei@ chemistry.msu.edu.

Supporting Information Available: Selected NMR spectra and images of the particle exclusion assay at low magnification. 
UDP-GlcA, thus competing for the limited intracellular pool of UDP-GlcA and further reducing the amount of HA produced. ${ }^{[13,14]} 4-\mathrm{MU}$ can reduce proliferation, motility, invasion, and metastatic properties of various types of cancer including prostate cancer and breast cancer. ${ }^{[12,15-18]}$ These observations have demonstrated the utility of HA biosynthesis inhibitors as potential antitumor agents.

Herein, we report an alternative approach to inhibit HA biosynthesis through potential early chain termination. We envision that if a modified Glc-NAc analog such as $\mathbf{1 - 3}$ is incorporated into an HA chain, as the C-3 position does not bear a free hydroxyl moiety, HA synthesis will be terminated, leading to a reduction of the amount of HA synthesized. The key to the success of this strategy is the incorporation of the potential chain terminators (e.g., 1-3) into the growing HA chain. The GlcNAc donor (i.e., UDP-GlcNAc) is synthesized inside the cells primarily from glucose through a series of enzymatic reactions. ${ }^{[19]}$ However, there exists a salvage pathway, which utilizes exogenous GlcNAc as the source for UDPGlcNAc. ${ }^{[20]}$ The salvage pathway has a broad substrate scope and is well tolerant of GlcNAc structural modifications, which can allow the transformation of a variety of GlcNAc analogs into UDP glycosyl donors. ${ }^{[21]}$ The HA synthase can potentially utilize the UDP-GlcNAc analog as a glycosyl donor and incorporate the modified GlcNAc into the HA chain. The chain termination strategy has been applied to inhibition of biosynthesis of a variety of glycans ${ }^{[22]}$ including sialyl Lewis $\mathrm{X}, \beta$-glucan, heparan sulfate, and chitin. ${ }^{[23-28]}$ Herein, we report the chemical synthesis of GlcNAc analogs and investigate their abilities to inhibit HA synthesis by cancer cells. A fluorine-containing GlcNAc analog showed high inhibitory activities toward HA synthesis and cancer cell proliferation.

\section{Results and Discussion}

Our synthetic targets are the 3-OMe, 3-oxo, and 3- $\mathrm{F}^{[29]}$ analogs of GlcNAc 4-6. The hydroxyl groups of these analogs are protected as acetates to reduce their hydrophilicity and increase their potential to cross cell membranes during cellular incubation. Acetate groups have been shown to significantly enhance intracellular concentrations of exogenous carbohydrates added to mammalian cells, which can then be deacetylated in situ by cytosolic esterases. ${ }^{[30]}$

In our initial route for the synthesis of these GlcNAc derivatives, we opted to use furanose oxazoline $\mathbf{8}$ as a key intermediate since it contains a free 3-OH moiety. Compound $\mathbf{8}$ was conveniently prepared in large quantities from commercially available GlcNAc $\mathbf{7}$ using anhydrous $\mathrm{FeCl}_{3}$ as a catalyst in acetone. ${ }^{[31]}$ With oxazoline 8 in hand, methylation of its free 3-OH group by $\mathrm{MeI}$ and $\mathrm{NaH}$ gave compound 9 in quantitative yield. Subsequent acidcatalyzed hydrolysis of compound $\mathbf{9}$ with $p$-toluene sulfonic acid (PTSA) furnished the desired 3-O-methyl- $N$-acetyl-o-glucosamine $\mathbf{1}$, which was acetylated using acetic anhydride in pyridine to give the product $\mathbf{4}$ in $50 \%$ overall yield over the two steps (Sch. 1).

Next we explored the synthesis of the 3-oxo GlcNAc derivative 5. Swern oxidation of 8 produced the ketone $\mathbf{1 0}$ in $92 \%$ yield (Sch. 2a). However, acid-catalyzed deprotection of $\mathbf{1 0}$ in a similar manner, as in the synthesis of compound $\mathbf{4}$, failed to provide the desired product 2. One possible explanation was that compound $\mathbf{2}$ was unstable under the acidic reaction 
condition. Based on this consideration, we designed an alternative route to avoid the acidic condition.

GlcNAc 7 was selectively benzylated at the anomeric position using concentrated $\mathrm{HCl}$ leading to compound $\mathbf{1 1},{ }^{[28]}$ which was followed by benzylidenation of the 4,6-hydroxyl groups generating compound $\mathbf{1 2}^{[32]}$ in an excellent $95 \%$ yield (Sch. 2b). Subsequent Swern oxidation of $\mathbf{1 2}$ produced 3-uloside derivative $\mathbf{1 3}$ in $90 \%$ yield. However, when subjected to the mild catalytic hydrogenation condition to remove the benzyl and benzylidene groups, compound $\mathbf{1 3}$ was transformed to multiple species. One of the major side products isolated was ketone 14, which was presumably formed due to a retro-Claisen reaction through nucleophilic attack of methanol on $\mathbf{2}$ (Sch. 2c). Therefore, compound $\mathbf{2}$ would most likely be unstable in a nucleophilic solvent such as water and was not pursued further.

We shifted our attention to the preparation of the $3 \mathrm{~F}-\mathrm{GlcNAc}$ derivative 6 . The first route explored was the substitution of the free 3-OH in oxazoline 8 by a fluorine atom. However, treatment of $\mathbf{8}$ with diethylaminosulfur trifluoride (DAST) gave a complex product mixture. Exchanging $\mathbf{8}$ in this reaction with compound $\mathbf{1 2}$ or the corresponding epimers containing axial 3-OH did not yield any desired fluorine substitution product. This was consistent with a literature report where the yield for fluorine substitution onto $\mathrm{C} 3$ of a GlcNAc analog was only $10 \% .{ }^{[29]}$

Kajihara and coworkers described that 6-OH of a glucosamine analog could be substituted with fluorine with a modest yield ( $\sim 38 \%)$ when phthalimide (Phth) was used as the protective group for the nitrogen. ${ }^{[33]}$ To test the effect of Phth on our fluorination reaction, we started from the Phth-containing glucosamine tetraacetate $15,{ }^{[34,35]}$ which was efficiently converted to $\beta$-benzyl glycoside $\mathbf{1 6}^{[36]}$ using $\mathrm{BF}_{3}$. $\mathrm{Et}_{2} \mathrm{O}$ in $\mathrm{CH}_{2} \mathrm{Cl}_{2}$ (Sch. 3). Subsequent acetate removal with $0.3 \mathrm{M} \mathrm{NaOMe}$ in a mixture of $\mathrm{MeOH}-\mathrm{CH}_{2} \mathrm{Cl}_{2}$ at $-10^{\circ} \mathrm{C}$ to $0^{\circ} \mathrm{C}$ produced triol 17 in $77 \%$ yield. The low reaction temperature was important to ensure the phthalimide ring was not opened by NaOMe. The $O-4$ and $O-6$ free hydroxyl groups in $\mathbf{1 7}$ were protected as a benzylidene acetal by treatment with benzaldehyde dimethyl acetal in the presence of a catalytic amount of camphorsulfonic acid to yield the benzylidene glycoside $18 .{ }^{[36]}$ To install the fluorine atom in the equatorial orientation, it was necessary to invert the configuration of the 3-OH group. This was accomplished through a four-step double-inversion protocol. Compound $\mathbf{1 8}$ was treated with $\mathrm{Tf}_{2} \mathrm{O}$ in $\mathrm{CH}_{2} \mathrm{Cl}_{2}$ in the presence of pyridine to convert the free hydroxyl group into a good leaving group (i.e., triflate). Displacement of the triflate by acetate via an $\mathrm{S}_{\mathrm{N}} 2$ manner yielded the 3-OAc glycoside, which was subsequently deprotected with $\mathrm{NaOMe}$ at $-10^{\circ} \mathrm{C}$ to produce the corresponding allosamine glycoside 19. Fluorination of compound 19 was accomplished using DAST, resulting in the inversion of configuration at $C-3$ to access the fluorinated analog mixed with a side product. Upon removal of the benzylidene-protecting group, we were able to purify the desired product $\mathbf{2 0}$ and identify the side product as $\mathbf{2 1} ; \mathbf{2 1}$ is presumably formed due to elimination of hydrogen fluoride followed by tautomerization and opening of the phthalimide ring. The overall yield of $\mathbf{2 0}$ from benzylidene glycoside $\mathbf{1 8}$ was $28 \%$.

To remove the Phth group in 20, it was initially treated with methylamine, but this attempt resulted in multiple degradation products. In contrast, heating $\mathbf{2 0}$ with excess ethylene 
diamine in n-butanol at $90^{\circ} \mathrm{C}$ allowed the access to the free amine derivative, which on subsequent acetylation provided the acetamide $\mathbf{2 2}$ in $80 \%$ yield (Sch. 3). Pd-catalyzed hydrogenolysis of $\mathbf{2 2}$ followed by acetylation led to the desired product $\mathbf{6}$ with the $\alpha$-anomer as the major product in $60 \%$ yield.

With compounds 4 and $\mathbf{6}$ in hand, we evaluated their abilities to inhibit HA biosynthesis in human pancreatic cancer cell line KP1-NL cells. 4-MU was used as a positive control. The amount of HA secreted into the culture medium as well as that residing on the cell surface was quantified by an ELISA-like assay using a Hyaluronan Assay Kit and reported on a per cell basis (Table 1). While compound $\mathbf{4}$ was not very effective in inhibiting HA biosynthesis, compound $\mathbf{6}$ significantly reduced the amount of HA formed, with an inhibition potency comparable to that of 4-MU.

As HA present in the pericellular matrix can create a barrier to the cell membrane, its presence can be visualized by the steric exclusion of fixed red blood cells to form a clear, halo-like area surrounding the KP1-NL cells (Fig. 3 and Fig. S1 in supporting information). Treatment of the cells with hyaluronidase, an enzyme capable of HA degradation, reduced the clear area around the cells to $48.2 \%$ (Fig. 3b; for quantification of the size of clear area see Fig. 3f). Compound 4 was much less potent, only leading to a small reduction to $93.1 \%$ of the vehicle control (Fig. 3d,f). In comparison, compound $6(100 \mu \mathrm{M})$ reduced the area to $40.9 \%$ (Fig. 3e,f), which was consistent with the ELISA analysis results supporting the idea that 6 could significantly inhibit HA synthesis. 4-MU $(100 \mu \mathrm{M})$ generated the largest change in the area under the same assay condition (Fig. 3c,f).

Next we analyzed the effects of compounds $\mathbf{4}$ and $\mathbf{6}$ on cell proliferation using an Alamar blue assay (Fig. 4). At the concentration of $100 \mu \mathrm{M}, 4-\mathrm{MU}$ did not show much inhibitory activities against the pancreatic cancer cell line KP1-NL cells. 3-Methoxy analog 4 (100 $\mu \mathrm{M}$ ) reduced the proliferation of the cancer cells to $60.5 \%$ of the DMSO control, while the 3-fluorine-containing analog 6 exhibited the highest antiproliferative activities, leading to a $91 \%$ reduction in cell numbers at $100 \mu \mathrm{M}$. The $\mathrm{IC}_{50}$ value of 6 was determined to be $30 \mu \mathrm{M}$.

In conclusion, we have developed synthetic routes to GlcNAc analogs bearing structural modifications at C-3 positions as potential inhibitors of HA biosynthesis. While the 3-OMe compound 4 was readily prepared, the intermediate to 3 -oxo analog was found to be unstable. To synthesize the 3-F-containing analog 6 , fluorination of the C-3 turned out to be highly challenging. The Phth group used for protection of the nitrogen was crucial, which gave better yield for the fluorination step compared to the previous report. ${ }^{[29]}$ Upon incubation of human pancreatic cell line with compounds 4 and 6 , the 3-F analog 6 significantly reduced the amount of HA both in secreted form and on the cancer cell surface. The inhibitory activity of $\mathbf{6}$ was further confirmed by a particle exclusion assay and $\mathbf{6}$ exhibited significant antiproliferative activities against pancreatic cancer cells. It is possible that besides the potential for serving as a chain terminator, 3-F GlcNAc analog 6 can reduce HA biosynthesis by interfering with other cellular processes. The exact mechanism will require further investigation. ${ }^{[37]}$ 


\section{Experimental Section}

\section{General Experimental Procedures}

All reactions were carried out under nitrogen with anhydrous solvents in flame-dried glassware, unless otherwise noted. Chemicals used were reagent grade as supplied except where noted. Compounds were visualized by UV light $(254 \mathrm{~nm})$ and by staining with a yellow solution containing $\mathrm{Ce}\left(\mathrm{NH}_{4}\right)_{2}\left(\mathrm{NO}_{3}\right)_{6}(0.5 \mathrm{~g})$ and $\left(\mathrm{NH}_{4}\right)_{6} \mathrm{Mo}_{7} \mathrm{O}_{24} 4 \mathrm{H}_{2} \mathrm{O}(24.0 \mathrm{~g})$ in $6 \% \mathrm{H}_{2} \mathrm{SO}_{4}(500 \mathrm{~mL})$. Flash column chromatography was performed on silica gel 60 (230400 mesh). NMR spectra were referenced using residual $\mathrm{CHCl}_{3}\left(\delta^{1} \mathrm{H}\right.$ NMR $\left.7.26 \mathrm{ppm}\right)$ and $\mathrm{CDC1}_{3}\left(\delta^{13} \mathrm{C}\right.$ NMR $\left.77.0 \mathrm{ppm}\right)$. Peak and coupling constant assignments are based on ${ }^{1} \mathrm{H}$ NMR, ${ }^{1} \mathrm{H}-{ }^{1} \mathrm{H}$ gCOSY, and/or ${ }^{1} \mathrm{H}_{-}{ }^{13} \mathrm{C}$ gHMQC and ${ }^{1} \mathrm{H}_{-}{ }^{13} \mathrm{C}$ gHMBC experiments.

\section{2-Methyl-(1,2-dideoxy-5,6-O-isopropylidene- $a$-o-glucofurano)-[2,1-d]-2-oxazoline (8) ${ }^{[38]}$}

Anhydrous $\mathrm{FeCl}_{3}(15 \mathrm{~g}, 0.092 \mathrm{~mol})$ was added to a suspension of 2-acetamido-2-deoxy-Dglucopyranose 7 (10 g, $0.068 \mathrm{~mol})$ in dry acetone $(200 \mathrm{~mL})$, and the mixture was stirred and heated to reflux for $20 \mathrm{~min}$ with exclusion of moisture. The solution was cooled to $0^{\circ} \mathrm{C}$, followed by addition of triethylamine $(35 \mathrm{~mL})$, acetone $(135 \mathrm{~mL})$, and a solution of sodium bicarbonate $(21.3 \mathrm{~g})$ in water $(135 \mathrm{~mL})$ with continuous stirring. Acetone, triethylamine, and some water were then removed in vacuo at $30^{\circ} \mathrm{C}$. The mixture was extracted with diethyl ether $(5 \times 200 \mathrm{~mL})$ and the combined extracts dried over $\mathrm{MgSO}_{4}$ and concentrated at $\mathrm{rt}$ to give compound $\mathbf{8}$ as brownish syrup (7.15 g, 65\%). The ${ }^{1} \mathrm{H}$ NMR spectrum is identical to what is reported in the literature. ${ }^{[38]}{ }^{1} \mathrm{H} \mathrm{NMR}\left(600 \mathrm{MHz}, \mathrm{CDCl}_{3}\right) \delta 1.33\left(\mathrm{~s}, 3 \mathrm{H}, \mathrm{CH}_{3}\right), 1.39$ $\left(\mathrm{s}, 3 \mathrm{H}, \mathrm{CH}_{3}\right), 2.00\left(\mathrm{~s}, 3 \mathrm{H}, \mathrm{N}=\mathrm{COCH}_{3}\right), 2.92(\mathrm{~s}, 1 \mathrm{H}, \mathrm{OH}-3), 3.72(\mathrm{dd}, 1 \mathrm{H}, \hat{\mathcal{P}}=3.6,9.6 \mathrm{~Hz}$, H-4), 3.97 (dd, $1 \mathrm{H}, \hat{\mathcal{P}}=4.8,8.4 \mathrm{~Hz}, \mathrm{H}-6), 4.11\left(\mathrm{dd}, 1 \mathrm{H}, \hat{\mathcal{\beta}}=5.4,7.8 \mathrm{~Hz}, \mathrm{H}-6^{\prime}\right), 4.28-4.32$ (m, 1H, H-5), 4.39 (d, 1H, $\mathcal{P}=3 \mathrm{~Hz}, \mathrm{H}-3), 4.44(\mathrm{dd}, 1 \mathrm{H}, \mathcal{P}=1.2,4.8 \mathrm{~Hz}, \mathrm{H}-2), 6.14(\mathrm{~d}, \mathcal{P}=$ $4.8 \mathrm{~Hz}, \mathrm{H}-1)$.

\section{2-Methyl-(1,2-di-deoxy-3-methoxy-5,6-O-isopropylidene- $a$-o-glucofurano)-[2,1-d]-2- oxazoline (9)}

Compound $8(0.4 \mathrm{~g}, 1.64 \mathrm{mmol})$ was dissolved in DMF $(15 \mathrm{~mL})$ and cooled to $0^{\circ} \mathrm{C} . \mathrm{NaH}$ $(0.08 \mathrm{~g}, 3.29 \mathrm{mmol})$ was added in three portions with vigorous stirring followed by dropwise addition of MeI $(0.15 \mathrm{~mL}, 2.47 \mathrm{mmol})$. The reaction mixture was allowed to warm up to rt. After $3 \mathrm{~h}$, DMF was evaporated in vacuo and the residue coevaporated twice with toluene. The resultant residue was dissolved in $\mathrm{CH}_{2} \mathrm{Cl}_{2}(20 \mathrm{~mL})$ and washed with ice cold water and the aqueous phase extracted twice with $\mathrm{CH}_{2} \mathrm{Cl}_{2}(2 \times 20 \mathrm{~mL})$. The organic phases were combined, washed with brine $(30 \mathrm{~mL})$, and dried with $\mathrm{Na}_{2} \mathrm{SO}_{4}$. Upon filtration and concentration in vacuo, compound 9 was obtained in $96 \%$ yield $(0.4 \mathrm{~g})$. $[\alpha]_{\mathrm{D}}^{20}-15.5(c=1$, $\left.\mathrm{CH}_{2} \mathrm{Cl}_{2}\right) ;{ }^{1} \mathrm{H} \mathrm{NMR}\left(600 \mathrm{MHz}, \mathrm{CDCl}_{3}\right) \delta 1.27\left(\mathrm{~s}, 3 \mathrm{H}, \mathrm{CH}_{3}\right), 1.33\left(\mathrm{~s}, 3 \mathrm{H}, \mathrm{CH}_{3}\right), 1.94(\mathrm{~s}, 3 \mathrm{H}$, $\left.\mathrm{N}=\mathrm{CC}_{3} \mathrm{H}_{3}\right), 3.40\left(\mathrm{~s}, 3 \mathrm{H}, \mathrm{OCH}_{3}\right), 3.71(\mathrm{dd}, 1 \mathrm{H}, \mathcal{P}=3.6,9 \mathrm{~Hz}, \mathrm{H}-4), 3.77(\mathrm{~d}, 1 \mathrm{H}, \mathcal{P}=4.2 \mathrm{~Hz}$, H-3), 3.91-3.94 (m, 1H, H-6), 3.97-3.99 (m, 1H, H-6'), 4.21 (m, 1H, H-5), 4.42 (dd, 1H, $\hat{\beta}$ $=1.8,6 \mathrm{~Hz}, \mathrm{H}-4), 6.01(\mathrm{~d}, 1 \mathrm{H}, \mathcal{\beta}=6.6 \mathrm{~Hz}, \mathrm{H}-1) ;{ }^{13} \mathrm{C} \mathrm{NMR}\left(150 \mathrm{~Hz}, \mathrm{CDCl}_{3}\right) \delta 14.3 .25 .5$, $26.99,57.98,67.0,72.7,74.8,81.5,83.7,107.1,109.2,167.2$. HRMS C ${ }_{12} \mathrm{H}_{20} \mathrm{NO}_{5}\left[\mathrm{M}+\mathrm{H}^{+}\right]$ calc. 258.1341 found 258.1333 . 


\section{1,4,6-Tri-O-acetyl-2-acetamido-2-deoxy-3-methoxy-- $\beta$-o-glucopyranoside (4)}

Compound 9 (0.204 g, $0.793 \mathrm{mmol})$ was dissolved in 1:2 $\mathrm{H}_{2} \mathrm{O} / \mathrm{THF}$ mixture $(10 \mathrm{~mL}: 20 \mathrm{~mL})$ and $p$-toluenesulfonic acid $(0.06 \mathrm{~g}, 0.264 \mathrm{mmol})$ was added to the reaction mixture then stirred overnight. The reaction was quenched with $\mathrm{Et}_{3} \mathrm{~N}$ to a neutral $\mathrm{pH}$ and the solvents were evaporated in vacuo. The residue was washed several times with $\mathrm{CH}_{2} \mathrm{Cl}_{2}$ and the resultant white powder dried under vacuum. The residue was then dissolved in pyridine (8 $\mathrm{mL}) . \mathrm{Ac}_{2} \mathrm{O}(0.5 \mathrm{~mL})$ was added and the reaction mixture was stirred at $\mathrm{rt}$ overnight. The reaction mixture was concentrated. The residue was dissolved in $\mathrm{CH}_{2} \mathrm{Cl}_{2}$, washed with $\mathrm{H}_{2} \mathrm{O}$ and brine, dried over $\mathrm{Na}_{2} \mathrm{SO}_{4}$, and purified by column chromatography $\left(\mathrm{CH}_{2} \mathrm{Cl}_{2} / \mathrm{MeOH}\right.$,

8:1) to give compound 4 in 50\% (0.143 g) yield over two steps. $[\alpha]_{\mathrm{D}}^{20}+10.5(c=1$, $\mathrm{CH}_{2} \mathrm{Cl}_{2}$ ); ${ }^{1} \mathrm{H} \mathrm{NMR}\left(600 \mathrm{MHz}, \mathrm{CDCl}_{3}\right) \delta 1.99\left(\mathrm{~s}, 3 \mathrm{H}, \mathrm{NHCOCH}_{3}\right), 2.07$ (s, 3H, $\mathrm{COCH}_{3}$ ), $2.10\left(\mathrm{~s}, 3 \mathrm{H}, \mathrm{COCH}_{3}\right), 2.11$ (s, $\left.3 \mathrm{H}, \mathrm{COCH}_{3}\right), 3.40\left(\mathrm{~s}, 3 \mathrm{H}, \mathrm{OCH}_{3}\right), 3.75-3.84(\mathrm{~m}, 3 \mathrm{H}, \mathrm{H}-2$, H-4, H-5), 4.09 (dd, 1H, $\hat{\mathcal{P}}=2.4,10.8 \mathrm{~Hz}, \mathrm{H}-6$ ), 4.23 (dd, $\left.1 \mathrm{H}, \hat{\mathcal{P}}=4.5,12 \mathrm{~Hz}, \mathrm{H}-6^{\prime}\right), 5.02$ (t, $1 \mathrm{H}, \hat{\mathcal{P}}=8.4 \mathrm{~Hz}, \mathrm{H}-3), 5.70(\mathrm{~d}, 1 \mathrm{H}, \hat{\mathcal{P}}=7.2 \mathrm{~Hz}, \mathrm{H}-1), 5.89(\mathrm{~d}, 1 \mathrm{H}, \hat{\mathcal{\beta}}=6.6 \mathrm{~Hz}, \mathrm{CONH}) ;{ }^{13} \mathrm{C}$ NMR $\left(125 \mathrm{~Hz}, \mathrm{CDCl}_{3}\right)$ 20.8, 20.84, 20.9, 23.4, 53.8, 58.0, 62.0, 68.5, 72.9, 79.2, 91.97, 169.4, 169.41, 170.2, 170.7. HRMS C ${ }_{15} \mathrm{H}_{23} \mathrm{NO}_{9} \mathrm{Na}\left[\mathrm{M}+\mathrm{Na}^{+}\right]$calc. 384.1271 found 384.1259 .

\section{Benzyl-2-acetamido-2-deoxy- $a$-o-glucopyranoside (11)}

$N$-Acetyl glucosamine $7(6.00 \mathrm{~g}, 27.1 \mathrm{mmol})$ was dissolved in benzyl alcohol $(50 \mathrm{~mL})$ and concentrated $\mathrm{HCl}(2.9 \mathrm{~mL})$ was added. The mixture was heated to $90^{\circ} \mathrm{C}$ for $3 \mathrm{~h}$, cooled to rt, and then poured onto $500 \mathrm{~mL} \mathrm{Et}_{2} \mathrm{O}$ and stored overnight at $-20^{\circ} \mathrm{C}$. The resulting precipitate was recovered by filtration and rinsed with $\mathrm{Et}_{2} \mathrm{O}$ and hexanes to yield $17.64 \mathrm{~g}$ of crude material, which was purified by silica gel chromatography $\left(8 \%\right.$ to $15 \% \mathrm{MeOH} / \mathrm{CH}_{2} \mathrm{Cl}_{2}$ ) to provide 11 (5.98 g, 71\%) as white foam. Comparison of ${ }^{1} \mathrm{H}$ NMR with literature values confirmed the identity of compound 11..$^{[28] ~}{ }^{1} \mathrm{H}$ NMR $\left(500 \mathrm{MHz}, \mathrm{CD}_{3} \mathrm{OD}\right), \delta 1.95(\mathrm{~s}, 3 \mathrm{H}$, $\left.\mathrm{COCH}_{3}\right), 3.37-3.39(\mathrm{~m}, 1 \mathrm{H}), 3.69-3.73(\mathrm{~m}, 3 \mathrm{H}), 3.82(\mathrm{~d}, 1 \mathrm{H}, \hat{\mathcal{\beta}}=9.5 \mathrm{~Hz}), 3.89(\mathrm{dd}, 1 \mathrm{H}, \hat{\mathcal{\beta}}$ $=3.5,11 \mathrm{~Hz}), 4.49(\mathrm{~d}, 1 \mathrm{H}, \hat{\mathcal{P}}=12 \mathrm{~Hz}), 4.74(\mathrm{~d}, 1 \mathrm{H}, \hat{\mathcal{P}}=11.5 \mathrm{~Hz}), 7.28-7.40(\mathrm{~m}, 5 \mathrm{H}$, aromatic).

\section{Benzyl-2-acetamido-2-deoxy-4,6-O-benzylidene- $a$-o-glucopyranoside (12)}

Compound 11 (0.412 g, $1.32 \mathrm{mmol})$ was dissolved in DMF $(20 \mathrm{~mL})$ followed by the addition of benzaldehyde dimethyl acetal $(0.6 \mathrm{~mL}, 3.97 \mathrm{mmol})$ and a catalytic amount of $p$ toluenesulfonic acid $(0.123 \mathrm{~g}, 0.53 \mathrm{mmol})$. The reaction mixture was stirred for $3 \mathrm{~h}$. DMF was removed in vacuo and the resultant white residue was suspended in saturated sodium bicarbonate solution. Upon filtration, the residue was washed several times with hexanes/ EtOAc/ $\mathrm{CH}_{2} \mathrm{Cl}_{2}$ (4/1/0.5) solvent system then dried under vacuum to afford compound $\mathbf{1 2}$ in $95 \%$ yield $(0.5 \mathrm{~g})$. Comparison of ${ }^{1} \mathrm{H}$ NMR with reported literature values confirmed the identity of compound $12 .{ }^{[32]}{ }^{1} \mathrm{H}$ NMR $\left(600 \mathrm{MHz}, \mathrm{CDCl}_{3}\right) \delta 1.82\left(\mathrm{~s}, 3 \mathrm{H}, \mathrm{CH}_{3}\right), 3.59(\mathrm{t}, 1 \mathrm{H}$, $\hat{\mathcal{P}}=9 \mathrm{~Hz}, \mathrm{H}-6), 3.75\left(\mathrm{t}, 1 \mathrm{H}, \hat{\mathcal{\beta}}=10.2 \mathrm{~Hz}, \mathrm{H}-6^{\prime}\right), 3.84-3.91(\mathrm{~m}, 1 \mathrm{H}, \mathrm{H}-5), 3.92-3.95(\mathrm{~m}, 1 \mathrm{H}$, $\mathrm{H}-4), 4.23-4.26$ (m, 2H, H-2, H-3), 4.93 (d, $\left.1 \mathrm{H}, \mathcal{P}=12 \mathrm{~Hz}, \mathrm{CH}_{2} \mathrm{Ph}\right), 4.74$ (d, $1 \mathrm{H}, \mathcal{P}=12$ $\left.\mathrm{Hz}, \mathrm{CH}_{2} \mathrm{Ph}\right), 4.93(\mathrm{~d}, 1 \mathrm{H}, \hat{\mathcal{P}}=3.5 \mathrm{~Hz}, \mathrm{H}-1), 5.57(\mathrm{~s}, 1 \mathrm{H}, \mathrm{CHPh}), 5.82(\mathrm{~d}, 1 \mathrm{H}, \hat{\mathcal{P}}=8.4 \mathrm{~Hz}$, $\mathrm{CONH}), 7.33-7.51$ (m, 10H, aromatic). 


\section{Benzyl-2-acetamido-2-deoxy-4,6-O-benzylidene-3-oxo- $a$-o-glucopyranoside (13)}

To a solution of $\mathrm{COCl}_{2}(0.11 \mathrm{~mL}, 1.25 \mathrm{mmol})$ and DMSO $(0.16 \mathrm{~mL}, 2.23 \mathrm{mmol})$ in $\mathrm{CH}_{2} \mathrm{Cl}_{2}$ $(30 \mathrm{~mL})$ cooled to $-78^{\circ} \mathrm{C}$ and stirred for 20 min was added compound $12(0.36 \mathrm{~g}, 0.894$ mmol) dissolved in $\mathrm{CH}_{2} \mathrm{Cl}_{2}(20 \mathrm{~mL})$. After $20 \mathrm{~min}, \mathrm{Et}_{3} \mathrm{~N}(0.63 \mathrm{~mL}, 4.47 \mathrm{mmol})$ was added and the reaction mixture allowed to warm to $\mathrm{rt}$ then quenched with $\mathrm{H}_{2} \mathrm{O}(100 \mathrm{~mL})$. The aqueous layer was extracted with $\mathrm{CH}_{2} \mathrm{Cl}_{2}(50 \mathrm{~mL})$. The organic layers were combined and washed with brine and dried over $\mathrm{MgSO}_{4}$. Compound 13 was obtained in $90 \%$ yield $(0.32 \mathrm{~g})$ by recrystallization from hexanes/EtOAc/ $\mathrm{CH}_{2} \mathrm{Cl}_{2}(5 / 1 / 0.5)$. $[\alpha]_{\mathrm{D}}^{20}+38.8(c=0.1$, $\mathrm{CH}_{2} \mathrm{Cl}_{2}$ ); ${ }^{1} \mathrm{H}$ NMR $\left(500 \mathrm{MHz}, \mathrm{CDCl}_{3}\right) \delta 2.00\left(\mathrm{~s}, 3 \mathrm{H}, \mathrm{CH}_{3}\right), 3.90$ (t, $\left.1 \mathrm{H}, \hat{\mathcal{P}}=10.5 \mathrm{~Hz}, \mathrm{H}-6\right)$, $4.11-4.16(\mathrm{~m}, 1 \mathrm{H}), 4.29$ (dd, $\left.1 \mathrm{H}, \mathcal{P}=5,10.5 \mathrm{~Hz}, \mathrm{H}-6^{\prime}\right), 4.37$ (d, $\left.1 \mathrm{H}, \mathcal{P}=10.5 \mathrm{~Hz}, \mathrm{H}-4\right)$, $4.50\left(\mathrm{~d}, 1 \mathrm{H}, \hat{\mathcal{\beta}}=12 \mathrm{~Hz}, \mathrm{CH}_{2} \mathrm{Ph}\right), 4.69\left(\mathrm{~d}, 1 \mathrm{H}, \hat{\mathcal{\beta}}=12 \mathrm{~Hz}, \mathrm{CH}_{2} \mathrm{Ph}\right), 4.95-4.97$ (m, 1H, H-2), 5.41 (d, $1 \mathrm{H}, \hat{\mathcal{P}}=4.5 \mathrm{~Hz}, \mathrm{H}-1), 5.56$ (s, 1H, CHPh), 6.22 (d, $1 \mathrm{H}, \hat{\mathcal{P}}=8.0 \mathrm{~Hz}, \mathrm{CONH}), 7.25-$ 7.49 (m, 10H, aromatic); ${ }^{13} \mathrm{C}$ NMR $\left(125 \mathrm{~Hz}, \mathrm{CDCl}_{3}\right) \delta 23.2,59.1,66.6,69.6,70.8,77.0$, $77.2,77.5,82.9,100.8,102.2,126.6,128.2,128.6,128.9,129.6,136.5,170.1,195.2$. HRMS $\mathrm{C}_{22} \mathrm{H}_{24} \mathrm{NO}_{6}\left[\mathrm{M}+\mathrm{H}^{+}\right]$calc. 398.1580 found 398.1577 .

\section{Benzyl-3,4,6-tri-O-acetyl-2-deoxy 2-phthalamido- $\beta$-o-glucopyranoside (16)}

Compound 15 (2.2 g, $4.61 \mathrm{mmol})$ was dissolved in $\mathrm{CH}_{2} \mathrm{Cl}_{2}(30 \mathrm{~mL})$, followed by addition of $\mathrm{BnOH}(1.1 \mathrm{~mL}, 9.22 \mathrm{mmol}) . \mathrm{BF}_{3} \mathrm{OEt}_{2}(1.75 \mathrm{~mL}, 11.4 \mathrm{mmol})$ was added dropwise and the reaction mixture was stirred at $\mathrm{rt}$ for $24 \mathrm{~h}$. The mixture was diluted with $\mathrm{CH}_{2} \mathrm{Cl}_{2}(20 \mathrm{~mL})$ and washed with saturated $\mathrm{NaHCO}_{3}(3 \times 20 \mathrm{~mL})$. The aqueous layer was extracted with $\mathrm{CH}_{2} \mathrm{Cl}_{2}(60 \mathrm{~mL})$ and the combined organic phases were dried over $\mathrm{Na}_{2} \mathrm{SO}_{4}$, filtered, concentrated, and purified by column purification (hexanes/EtOAc 3:2) to yield compound $16(1.92 \mathrm{~g}, 79 \%)$. Comparison of ${ }^{1} \mathrm{H}$ NMR with reported literature values confirmed the identity of compound $16 .{ }^{[36]}{ }^{1} \mathrm{H}$ NMR $\left(600 \mathrm{MHz}, \mathrm{CDCl}_{3}\right) \delta 1.86\left(\mathrm{~s}, 3 \mathrm{H}, \mathrm{COCH}_{3}\right), 2.02$ (s, $\left.3 \mathrm{H}, \mathrm{COCH}_{3}\right), 2.13\left(\mathrm{~s}, 3 \mathrm{H}, \mathrm{COCH}_{3}\right), 3.85-3.88(\mathrm{~m}, 1 \mathrm{H}, \mathrm{H}-5), 4.19(\mathrm{dd}, 1 \mathrm{H}, \hat{\beta}=2.4,12 \mathrm{~Hz}$, H-6), 4.33-4.39 (m, 2H, H-2, H-6'), 4.53 (d, 1H, $\hat{\mathcal{P}}=12 \mathrm{~Hz}, \mathrm{CHPh}), 4.84(\mathrm{~d}, 1 \mathrm{H}, \hat{\mathcal{P}}=12.6$ $\mathrm{Hz}, \mathrm{CHPh}), 5.17(\mathrm{t}, 1 \mathrm{H}, \hat{\mathcal{P}}=9.6 \mathrm{~Hz}, \mathrm{H}-4) 5.37(\mathrm{~d}, 1 \mathrm{H}, \hat{\mathcal{P}}=8.4 \mathrm{~Hz}, \mathrm{H}-1), 5.77(\mathrm{dd}, 1 \mathrm{H}, \hat{\mathcal{P}}=$ 9.0, 10.2 Hz, H-3), 7.08-7.79 (m, 9H, aromatic).

\section{Benzyl-4,6-O-benzylidene-2-deoxy-2-phthalamido- $\beta$-o-glucopyranoside (18)}

Compound 16 (1.88 g, $3.79 \mathrm{mmol}$ ) was dissolved in $\mathrm{MeOH} / \mathrm{CH}_{2} \mathrm{Cl}_{2}$ solvent mixture (3:2, 20 $\mathrm{mL}$ ) and cooled to $-10^{\circ} \mathrm{C}$ followed by dropwise addition of $0.3 \mathrm{M} \mathrm{NaOMe}$ in $\mathrm{MeOH}(6 \mathrm{~mL})$. Upon completion of the reaction as established by TLC in $2 \mathrm{~h}$, the reaction mixture was neutralized with Amberlite ion exchange resin to $\mathrm{pH}$ 7. The crude triol 17 was concentrated and the residue was coevaporated with toluene twice followed by drying under vacuum overnight. The residue was then suspended in $\mathrm{CH}_{3} \mathrm{CN}(15 \mathrm{~mL})$ and $\mathrm{PhCH}\left(\mathrm{OCH}_{3}\right)_{2}(0.7 \mathrm{~mL}$, $4.55 \mathrm{mmol})$ was added, followed by addition of camphorsulfonic acid $(0.2 \mathrm{~g}, 0.87 \mathrm{mmol})$. The mixture was stirred for $3 \mathrm{~h}$ then quenched with $\mathrm{Et}_{3} \mathrm{~N}$ upon completion of reaction as confirmed by TLC. Solvents were evaporated and the residue was purified by column chromatography (hexanes/EtOAc 3:1) to yield compound $\mathbf{1 8}(1.42 \mathrm{~g}, 77 \%)$. The identity of compound 18 was confirmed by comparison with reported literature values. ${ }^{[36]}{ }^{1} \mathrm{H}$ NMR (600 MHz, CDCl 3 ) 3.62-3.67 (m, 2H, H-4, H-6), 3.85-3.88 (m, 1H, H-6), 4.29-4.32 (m, 1H, H-2), 4.42 (dd, $1 \mathrm{H}, \hat{\mathcal{P}}=4.8,10.8 \mathrm{~Hz}, \mathrm{H}-5), 4.52$ (d, $1 \mathrm{H}, \hat{\mathcal{P}}=12.6 \mathrm{~Hz}, \mathrm{CHPh}), 4.63-$ 
$4.67(\mathrm{~m}, 1 \mathrm{H}, \mathrm{H}-3), 4.84(\mathrm{~d}, 1 \mathrm{H}, \mathcal{P}=12 \mathrm{~Hz}, \mathrm{CHPh}), 5.28(\mathrm{~d}, 1 \mathrm{H}, \mathcal{P}=8.4 \mathrm{~Hz}, \mathrm{H}-1), 5.58$ (s, $1 \mathrm{H} \mathrm{CHPh}) 7.03-7.79$ (m, 14H, aromatic).

\section{Benzyl-2-deoxy-3-fluoro-2-phthalamido- $\beta$-o-glucopyranoside (20)}

To a solution of compound $\mathbf{1 8}(0.833 \mathrm{~g}, 1.71 \mathrm{mmol})$ dissolved in $\mathrm{CH}_{2} \mathrm{Cl}_{2}(30 \mathrm{~mL})$, pyridine $(0.7 \mathrm{~mL}, 8.54 \mathrm{mmol})$ was added and the mixture was cooled to $-20^{\circ} \mathrm{C}$. $\mathrm{Tf}_{2} \mathrm{O}(0.6 \mathrm{~mL}, 3.42$ mmol) dissolved in $\mathrm{CH}_{2} \mathrm{Cl}_{2}(1 \mathrm{~mL})$ was added drop-wise and the reaction mixture was allowed to warm up to rt within $1.5 \mathrm{~h}$. The reaction mixture was diluted with $\mathrm{CH}_{2} \mathrm{Cl}_{2}$ (20 $\mathrm{mL}$ ) and then quenched with saturated $\mathrm{NaCHO}_{3}$, washed with water and brine, dried over $\mathrm{Na}_{2} \mathrm{SO}_{4}$, and concentrated under reduced pressure at ambient temperature $\left(25-30^{\circ} \mathrm{C}\right)$. The resultant yellow syrup was dissolved in toluene, TBAOAc (3.09 g, $10.26 \mathrm{mmol})$ added, and the mixture stirred at $65^{\circ} \mathrm{C}$ overnight. The mixture was allowed to cool to rt then diluted with EtOAc. Solvents were evaporated and the resultant residue was purified by column chromatography (hexanes/EtOAc 3.5:1) to yield benzyl-3- $O$-acetyl-2-deoxy-4,6- $O$ -

benzylidene-2-phthalamido- $\beta$-D-allopyranoside. $[\alpha]_{\mathrm{D}}^{20}-47.0\left(c=0.5, \mathrm{CH}_{2} \mathrm{Cl}_{2}\right) ;{ }^{1} \mathrm{H}$ NMR $\left(600 \mathrm{MHz}, \mathrm{CDCl}_{3}\right) \delta 2.07\left(\mathrm{~s}, 3 \mathrm{H}, \mathrm{COCH}_{3}\right), 3.86-3.93(\mathrm{~m}, 2 \mathrm{H}, \mathrm{H}-4, \mathrm{H}-6), 4.18-4.22(\mathrm{~m}, 1 \mathrm{H}$, H-6), 4.44-4.49 (m, 2H, H-2, H-4), 4.64 (d, 1H, $\mathcal{\beta}=10.8 \mathrm{~Hz}, \mathrm{CHPh}$ ), 4.93 (d, CHPh $\hat{\beta}=12$ $\mathrm{Hz}, \mathrm{CHPh}$ ), 5.61 (s, 1H, CHPh), 5.77-5.78 (m, 1H, H-3), 6.15 (d, 1H, $\mathcal{P}=8.4, \mathrm{H}-1), 7.21-$ 7.84 (m, 14H, aromatic). HRMS $\mathrm{C}_{30} \mathrm{H}_{27} \mathrm{NO}_{8} \mathrm{Na}\left[\mathrm{M}+\mathrm{Na}^{+}\right]$calc. 552.1634 found 552.1595. Benzyl-3- $O$-acetyl-2-deoxy-4,6- $O$-benzylidene-2-phthalamido- $\beta$-D-allopyranoside $(0.6 \mathrm{~g}$, $1.13 \mathrm{mmol})$ was dissolved in $\mathrm{MeOH} / \mathrm{CH}_{2} \mathrm{Cl}_{2}(3: 2,10 \mathrm{~mL})$, cooled to $-10^{\circ} \mathrm{C}$, and treated with $0.3 \mathrm{M} \mathrm{NaOMe}$ solution in methanol $(3 \mathrm{~mL})$. After $1 \mathrm{~h}$, the reaction was complete as confirmed by TLC and subsequently quenched with Amberlite ion exchange resin (IR 120) to $\mathrm{pH}$ 7. Solvents were evaporated and the resultant white solid was coevaporated with toluene $(3 \times 10 \mathrm{~mL})$ then dried under vacuum for $2 \mathrm{~h}$. The allosamine analog 19 was dissolved in $\mathrm{CH}_{2} \mathrm{Cl}_{2}(10 \mathrm{~mL})$ in a $50-\mathrm{mL}$ falcon tube and cooled to $-5^{\circ} \mathrm{C}$. This was followed by dropwise addition of DAST $(0.27 \mathrm{~mL}, 6.78 \mathrm{mmol})$ and the reaction mixture was allowed to warm to rt over $3 \mathrm{~h}$. The reaction mixture was cooled to $-5^{\circ} \mathrm{C}$ followed by dropwise addition of $\mathrm{MeOH}$ to destroy the excess DAST, concentrated, and passed through a short silica column. The resultant mixture of compound was dissolved in $\mathrm{MeOH} / \mathrm{CH}_{2} \mathrm{Cl}_{2}(3: 2,10$ $\mathrm{mL})$ followed by addition of $\mathrm{AcCl}(0.16 \mathrm{~mL}, 2.26 \mathrm{mmol})$, then stirred overnight at $\mathrm{rt}$. The reaction mixture was quenched with $\mathrm{Et}_{3} \mathrm{~N}$ to $\mathrm{pH}$ 7. Solvents were evaporated in vacuo and the resultant residue was purified by column chromatography (hexanes/EtOAc/MeOH 3:1:0.1) to acquire the desired compound $20(0.17 \mathrm{~g}, 28 \%$ yield from 18) and elimination product $21(0.07 \mathrm{~g}, 14.5 \%) .20:[\alpha]_{\mathrm{D}}^{20}-64.0\left(c=0.5, \mathrm{CH}_{2} \mathrm{Cl}_{2}\right) ;{ }^{1} \mathrm{H} \mathrm{NMR}\left(600 \mathrm{MHz}, \mathrm{CDCl}_{3}\right)$ $\delta .29(\mathrm{~s}, 1 \mathrm{H}, \mathrm{OH}), 3.11(\mathrm{~s}, 1 \mathrm{H}, \mathrm{OH}), 3.52-3.54(\mathrm{~m}, 1 \mathrm{H}, \mathrm{H}-5), 3.89-3.99(\mathrm{~m}, 3 \mathrm{H}, \mathrm{H}-4, \mathrm{H}-6$, H-6') $4.34-4.39$ (m, 1H, H-2), 4.53 (d, 1H, $\mathcal{P}=12 \mathrm{~Hz}, \mathrm{CHPh}), 4.79$ (d, $1 \mathrm{H}, \hat{\mathcal{P}}=12 \mathrm{~Hz}$, CHPh), 5.13-5.25 (m, 3H), 7.05-7.26 (m, 5H, aromatic), 7.22-7.80 (m, 4H, aromatic); ${ }^{19} \mathrm{~F}$ NMR (282 MHz, $\mathrm{CDCl}_{3}$ ) -194.44 (dt, $1 \mathrm{~F}, \hat{\boldsymbol{P}}=51.9,13.8 \mathrm{~Hz}$ ). HRMS $\mathrm{C}_{21} \mathrm{H}_{20} \mathrm{NaO}_{6} \mathrm{NF}[\mathrm{M}+$ $\mathrm{Na}^{+}$] calc. 424.1167 found 424.1172 .

\section{Benzyl-3-deoxy-2-(methylcarbamoyl)benzoate-6-methoxy-4-oxo- $\beta$-o-glucopyranoside (21)}

$[\alpha]_{\mathrm{D}}^{20}-51.4\left(c=0.5, \mathrm{CH}_{2} \mathrm{Cl}_{2}\right) ;{ }^{1} \mathrm{H} \mathrm{NMR}\left(600 \mathrm{MHz}, \mathrm{CDCl}_{3}\right) 2.24(\mathrm{dd}, 1 \mathrm{H}, \hat{\mathcal{P}}=4.2,13.2 \mathrm{~Hz}$, $\mathrm{H}-3), 2.48(\mathrm{t}, 1 \mathrm{H}, \hat{\mathcal{P}}=13.2 \mathrm{~Hz}, \mathrm{H}-3), 3.32\left(\mathrm{~s}, 3 \mathrm{H}, \mathrm{OCH}_{3}\right), 3.36\left(\mathrm{~s}, 3 \mathrm{H}, \mathrm{OCH}_{3}\right), 3.73-3.74$ 
(m, 1H, H-5), 3.88-3.96 (m, 2H, H-6, H-6'), 4.43-4.48 (m, 1H, H-2), 4.58 (d, 1H, $\mathcal{P}=12$ $\mathrm{Hz}, \mathrm{CHPh}), 4.79(\mathrm{~d}, 1 \mathrm{H}, \hat{\mathcal{P}}=12 \mathrm{~Hz}, \mathrm{CHPh}), 5.33(\mathrm{~d}, 1 \mathrm{H}, \hat{\mathcal{P}}=8.4 \mathrm{~Hz}, \mathrm{H}-1), 7.08-7.16(\mathrm{~m}$, 5H, aromatic), 7.70-7.84 (m, 4H, aromatic); ${ }^{13} \mathrm{C} \mathrm{NMR}\left(150 \mathrm{~Hz}, \mathrm{CDCl}_{3}\right)$ 32.6, 49.4, 49.95, 50.6, 60.9, 71.2, 80.1, 98.7, 99.4, 123.3, 123.6, 127.6, 127.8, 127.9, 128.1, 128.3, 128.5, $131.4,131.5,131.7,134.0,167.6,167.8,204.4$, 204.7. HRMS C $23 \mathrm{H}_{29} \mathrm{~N}_{2} \mathrm{O}_{7}\left[\mathrm{M}+\mathrm{NH}^{+}\right]$ calc. 445.1975 found 445.1994 .

\section{Benzyl-4,6-tri-O-acetyl-2-acetamido-2-deoxy-3-fluoro- $\beta$-o-glucopyranoside (22)}

Compound 20 (0.34 g, $0.847 \mathrm{mmol})$ was dissolved in ${ }^{\mathrm{n}}$ butanol $(10 \mathrm{~mL})$ and treated with ethylene diamine $(6 \mathrm{~mL})$. The reaction mixture was heated at $90^{\circ} \mathrm{C}$ for $23 \mathrm{~h}$. Solvents were then removed under reduced pressure and the resultant residue was coevaporated with toluene $(3 \times 10 \mathrm{~mL})$, which was followed by drying in vacuo for $3 \mathrm{~h}$. The intermediate free amine was dissolved in pyridine $(10 \mathrm{~mL})$, followed by addition of $\mathrm{Ac}_{2} \mathrm{O}(6 \mathrm{~mL})$, and was stirred overnight at rt. The mixture was treated with $\mathrm{EtOH}$ to react with excess $\mathrm{Ac}_{2} \mathrm{O}$, concentrated, dissolved in $\mathrm{CH}_{2} \mathrm{Cl}_{2}$, washed with water and brine, and dried over $\mathrm{Na}_{2} \mathrm{SO}_{4}$, followed by purification by column chromatography (hexanes/EtOAc/ $\mathrm{CH}_{2} \mathrm{Cl}_{2} / \mathrm{MeOH}$, 2:1:1:0.2) to afford compound $22(0.27 \mathrm{~g}, 80 \%) .{ }^{1} \mathrm{H}$ NMR $\left(600 \mathrm{MHz}, \mathrm{CDCl}_{3}\right) \delta 1.94$ (s, 3H, $\left.\mathrm{NHCOCH}_{3}\right), 2.09\left(\mathrm{~s}, 3 \mathrm{H}, \mathrm{COCH}_{3}\right), 2.10\left(\mathrm{~s}, 3 \mathrm{H}, \mathrm{COCH}_{3}\right), 3.33-3.38$ (m, 1H, H-2), 3.663.67 (m, 1H, H-5), 4.14-4.17 (m, 1H, H-6), 4.27 (dd, 1H, $\left.\hat{\mathcal{P}}=5,12.5 \mathrm{~Hz}, \mathrm{H}-6^{\prime}\right) 4.57$ (d, 1H, $\hat{\mathcal{P}}=12.5 \mathrm{~Hz}, \mathrm{CHPh}), 4.88(\mathrm{~d}, 1 \mathrm{H}, \hat{\mathcal{P}}=12 \mathrm{~Hz}, \mathrm{CHPh}), 5.10-5.24$ (m, 3H, H-1, H-3, H-4), $5.78(\mathrm{~d}, 1 \mathrm{H}, \hat{\mathcal{\beta}}=7 \mathrm{~Hz}, \mathrm{CONH}) ;{ }^{19} \mathrm{~F}$ NMR $(282.2 \mathrm{MHz}, \mathrm{CDCl} 3)-193.26(\mathrm{dt}, 1 \mathrm{~F}, \hat{\mathcal{P}}=53.3$, $12.4 \mathrm{~Hz})$. HRMS $\mathrm{C}_{19} \mathrm{H}_{25} \mathrm{FNO}_{7}\left[\mathrm{M}+\mathrm{H}^{+}\right]$calc. 398.1615 found 398.1595 .

\section{1,4,6-Tri-O-acetyl-2-acetamido-2-deoxy-3-fluoro- $a$-o-glucopyranoside (6)}

Compound 22 (20 mg, $0.05 \mathrm{mmol}$ ) was dissolved in $\mathrm{MeOH}(6 \mathrm{~mL})$ and treated with $\mathrm{Pd} / \mathrm{C}$ (30 mg). The reaction mixture was the stirred under hydrogen for $36 \mathrm{~h}$ and the reaction confirmed as complete by TLC. The mixture was filtered and concentrated and the residue coevaporated with toluene $(3 \times 10 \mathrm{~mL})$ followed by drying under vacuum. The resultant residue was dissolved in pyridine $(3 \mathrm{~mL})$, treated with $\mathrm{Ac}_{2} \mathrm{O}(0.5 \mathrm{~mL})$, and stirred overnight at rt. The mixture was concentrated; washed with $1 \mathrm{M} \mathrm{HCl}$, saturated $\mathrm{NaHCO}_{3}$, and brine; and dried over $\mathrm{Na}_{2} \mathrm{SO}_{4}$. Column purification (hexanes/EtOAc, 1.5:1) afforded compound 6 $\left(15 \mathrm{mg}, 76 \%\right.$ yield over two steps). $[\alpha]_{\mathrm{D}}^{20}+10.1\left(c=1, \mathrm{CH}_{2} \mathrm{Cl}_{2}\right) ;{ }^{1} \mathrm{H} \mathrm{NMR}(600 \mathrm{MHz}$, $\left.\mathrm{CDCl}_{3}\right) \delta 2.03\left(\mathrm{~s}, 3 \mathrm{H}, \mathrm{NHCOCH}_{3}\right), 2.09\left(\mathrm{~s}, 3 \mathrm{H}, \mathrm{COCH}_{3}\right), 2.11\left(\mathrm{~s}, 3 \mathrm{H}, \mathrm{COCH}_{3}\right), 2.16(\mathrm{~s}, 3 \mathrm{H}$, $\mathrm{COCH}_{3}$ ), 3.93-3.96 (m, 1H, H-5), 4.06-4.09 (m, 1H, H-6), 4.22 (d, $1 \mathrm{H}, \hat{\mathcal{P}}=4.2,12.6 \mathrm{~Hz}$, H-6'), 4.58-4.69 (m, 2H, H-2, H-3), 5.25-5.30 (m, 1H, H-4), 5.52 (d, 1H, $\mathcal{P}=7.8 \mathrm{~Hz}, \mathrm{NH}$ ), $6.20(\mathrm{t}, 1 \mathrm{H}, \mathcal{P}=3 \mathrm{~Hz}, \mathrm{H}-1) ;{ }^{13} \mathrm{C}$ NMR $(150 \mathrm{~Hz}, \mathrm{CDCl} 3)$ 20.6, 20.7, 20.8, 23.2, 50.9, 50.96, $61.3,68.1,68.2,69.5,69.6,88.97,90.2,90.9,91.0,168.4,169.0,170.0,170.7 ;{ }^{19} \mathrm{~F}$ NMR (282.2 MHz, CDCl3) -194.24 (dt, 1F, $\mathcal{P}=50.8,13.5 \mathrm{~Hz}$,). HRMS C14H24N2O8F [M + $\mathrm{NH} 4^{+}$] calc. 367.1517 found 367.1512 .

\section{Determination of HA Concentration by an ELISA-Like Assay}

KP1-NL cells (passage 3$)$ were seeded in $35-\mathrm{mm}$ culture dishes $\left(6 \times 10^{5}\right.$ cells/dish) and cultured for $24 \mathrm{~h}$. Cells were further cultured in fresh medium containing each compound for $48 \mathrm{~h}$. The culture supernatants were collected and the cells were lysed by $1 \%$ Nonidet P- 40 , 
$140 \mathrm{mM} \mathrm{NaCl}, 10 \mathrm{mM}$ EDTA, and $20 \mathrm{mM}$ Tris- $\mathrm{HCl}$ (pH 7.4). HA released into the culture medium and accumulated in cell layers was quantified by an ELISA-like assay using HAbinding protein (HABP) according to the manufacturer's instructions for the Hyaluronan Assay Kit (Seikagaku Co., Tokyo, Japan). The absorbance at $490 \mathrm{~nm}$ (control wavelength, $630 \mathrm{~nm}$ ) of each well was measured by a microplate spectrophotometer xMark (Bio-Rad, Tokyo, Japan). The quantity of HA was expressed per live cell number. The viability of cells was assessed by trypan blue staining.

\section{Particle Exclusion Assay}

KP1-NL cells (passage 5) plated at $2.5 \times 10^{4}$ cells in a $35-\mathrm{mm}$ dish were cultured for $24 \mathrm{~h}$ and then further cultured for $48 \mathrm{~h}$ with or without $100 \mu \mathrm{M}$ of the compound of interest in fresh medium containing $0.1 \%$ DMSO. An aliquot of glutaraldehyde-stabilized sheep erythrocytes $\left(5 \times 10^{8}\right)$ in $0.75 \mathrm{~mL}$ of PBS was then added to the culture medium. After 15 min, the culture was observed using an inverted phase-contrast microscope (Olympus IMT-2). ${ }^{[39]}$ The sizes of the clear areas were quantified using ImageJ and the standard deviations of at least five areas in each image were reported.

\section{Estimation of Cell Proliferation}

Cell numbers were estimated using the Alamar Blue assay, which is based on the oxidationreduction reaction of cells. ${ }^{[40]}$ Briefly, KP1-NL cells (passage 3, 625 cells/well) were cultured overnight in $90 \mu \mathrm{L}$ of medium in 96-well flat-bottomed microplates (Iwaki Glass Co., Chiba, Japan) in triplicate and were further cultured for $72 \mathrm{~h}$ with or without $0.1 \mathrm{mM}$ of the test compound in freshly served medium containing 0.1\% DMSO. Alamar Blue working solution (10 $\mu \mathrm{L}$, BioSource, Camarillo, CA) was then added to each well and the plate was further incubated for $3 \mathrm{~h}$ at $37^{\circ} \mathrm{C}$ in a $\mathrm{CO}_{2}$ incubator. The fluorescence of each well was measured at ex $544 \mathrm{~nm}$ and em $590 \mathrm{~nm}$ using a Fluoroskan II (Japan Flow Laboratories, Tokyo, Japan). Reported values represented the means of replicate wells and the standard deviations for each are reported. The reaction was linear in the range of 300-3500 fluorescence units, corresponding to 300-20,000 KP1-NL cells/well.

\section{Supplementary Material}

Refer to Web version on PubMed Central for supplementary material.

\section{Acknowledgments}

We thank the National Institute of General Medical Sciences (R01 GM72667), NIH, for financial support of our work. This work was also partially supported by the Regional Innovation Strategy Support Program (City Area Type) of the Ministry of Education, Culture, Sports, Science and Technology of Japan.

\section{References}

1. Lapcik L Jr, Lapcik L, De Smedt S, Demeester J, Chabrecek P. Hyaluronan: preparation, structure, properties, and applications. Chem Rev. 1998; 98:2663-2684. [PubMed: 11848975]

2. Misra S, Ghatak S, Zoltan-Jones A, Toole BP. Regulation of multidrug resistance in cancer cells by hyaluronan. J Biol Chem. 2003; 278:25285-25288. [PubMed: 12738783]

3. Delpech B, Girard N, Bertrand P, Courel NM, Chauzy C, Delpech A. Hyaluronan: fundamental principles and applications in cancer. J Intern Med. 1997; 242:41-48. [PubMed: 9260565] 
4. Knudson W. Tumor associated hyaluronan: providing an extracellular matrix that facilitates invasion. Am J Pathol. 1996; 148:1721-1726. [PubMed: 8669457]

5. Franzmann EJ, Schroeder GL, Goodwin WJ, Weed DT, Fisher P, Lokeshwar VB. Expression of tumor markers hyaluronic acid and hyaluronidase (HYAL1) in head and neck tumors. Int J Cancer. 2003; 106:438-445. [PubMed: 12845686]

6. Posey JT, Soloway MS, Ekici S, Sofer M, Civantos F, Duncan RC, Lokeshwar VB. Evaluation of the prognostic potential of hyaluronic acid and hyaluronidase (HYAL1) for prostate cancer. Cancer Res. 2003; 63:2638-2644. [PubMed: 12750291]

7. Pirinen R, Tammi R, Tammi M, Hirvikoski P, Parkkinen JJ, Johansson R, Böhm J, Hollmén S, Kosma VM. Prognostic value of hyaluronan expression in non-small-cell lung cancer: increased stromal expression indicates unfavorable outcome in patients with adenocarcinoma. Int $\mathrm{J}$ Cancer. 2001; 95:12-17. [PubMed: 11241304]

8. Setälä LP, Tammi MI, Tammi RH, Eskelinen MJ, Lipponen PK, Ågren UM, Parkkinen J, Alhava EM, Kosma VM. Hyaluronan expression in gastric cancer cells is associated with local and nodal spread and reduced survival rate. Br J Cancer. 1999; 79:1133-1138. [PubMed: 10098747]

9. Lokeshwar VB, Öbek C, Soloway MS, Block NL. Tumor-associated hyaluronic acid: a new sensitive and specific urine marker for bladder cancer. Cancer Res. 1997; 57:773-777. [PubMed: 9044859]

10. Weigel PH, Hascall VC, Tammi M. Hyaluronan synthases. J Biol Chem. 1997; 272:13997-14000. [PubMed: 9206724]

11. Nakamura T, Takagaki K, Shibata S, Tanaka K, Higuchi T, Endo M. Hyaluronic-acid-deficient extracellular matrix induced by addition of 4-methylumbelliferone to the medium of cultured human skin fibroblasts. Biochem Biophys Res Commun. 1995; 208:470-475. [PubMed: 7695595]

12. Nakazawa H, Yoshihara S, Kudo D, Morohashi H, Kakizaki I, Kon A, Takagaki K, Sasaki M. 4Methylumbelliferone, a hyaluronan synthase suppressor, enhances the anticancer activity of gemcitabine in human pancreatic cancer cells. Cancer Chemother Pharmacol. 2006; 57:165-170. and references cited therein. [PubMed: 16341905]

13. Kakizaki I, Kojima K, Takagaki K, Endo M, Kannagi R, Ito M, Maruo Y, Sato H, Yasuda T, Mita S, Kimata K, Itano N. A novel mechanism for the inhibition of hyaluronan biosynthesis by 4methylumbelliferone. J Biol Chem. 2004; 279:33281-33289. [PubMed: 15190064]

14. Kultti A, Pasonen-Seppänen S, Jauhiainen M, Rilla KJ, Kärnä R, Pyöriä E, Tammi RH, Tammi MI. 4-Methylumbelliferone inhibits hyaluronan synthesis by depletion of cellular UDP-glucuronic acid and downregulation of hyaluronan synthase 2 and 3. Exp Cell Res. 2009; 315:1914-1923. [PubMed: 19285976]

15. Kudo D, Kon A, Yoshihara S, Kakizaki I, Sasaki M, Endo M, Takagaki K. Effect of a hyaluronan synthase suppressor, 4-methylumbelliferone, on B16F-10 melanoma cell adhesion and locomotion. Biochem Biophys Res Commun. 2004; 321:783-787. [PubMed: 15358095]

16. Piccioni F, Malvicini M, Garcia MG, Rodriguez A, Atorrasagasti C, Kippes N, Buena ITP, Rizzo MM, Bayo J, Aquino J, Viola M, Passi A, Alaniz L, Mazzolini G. Antitumor effects of hyaluronic acid inhibitor 4-methylumbelliferone in an orthotopic hepatocellular carcinoma model in mice. Glycobiology. 2012; 22:400-410. [PubMed: 22038477]

17. Urakawa H, Nishida Y, Wasa J, Arai E, Zhuo L, Kimata K, Kozawa E, Futamura N, Ishiguro N. Inhibition of hyaluronan synthesis in breast cancer cells by 4-methylumbelliferone suppresses tumorigenicity in vitro and metastatic lesions of bone in vivo. Int J Cancer. 2012; 130:454-466. [PubMed: 21387290]

18. Lokeshwar VB, Lopez LE, Munoz D, Chi A, Shirodkar SP, Lokeshwar SD, Escudero DO, Dhir N, Altman N. Antitumor activity of hyaluronic acid synthesis inhibitor 4-methylumbelliferone in prostate cancer cells. Cancer Res. 2010; 70:2613-2623. [PubMed: 20332231]

19. Ghosh S, Blumenthal HJ, Davidson E, Roseman S. Glucosamine metabolism. V. Enzymatic synthesis of glucosamine 6-phosphate. J Biol Chem. 1960; 235:1265-1273. [PubMed: 13827775]

20. Boehmelt G, Wakeham A, Elia A, Sasaki T, Plyte S, Potter J, Yang YJ, Tsang E, Ruland J, Iscove NN, Dennis JW, Mak TW. Decreased UDP-GlcNAc levels abrogate proliferation control in EMeg32-deficient cells. EMBO J. 2000; 19:5092-5104. [PubMed: 11013212] 
21. Vocadlo DJ, Hang HC, Kim EJ, Hanover JA, Bertozzi CR. A chemical approach for identifying OGlcNAc modified proteins in cells. Proc Natl Acad Sci USA. 2003; 100:9116-9121. [PubMed: 12874386]

22. Gloster TM, Vocadlo DJ. Developing inhibitors of glycan processing enzymes as tools for enabling glycobiology. Nature Che mBiol. 2012; 8:683-694. and references cited therein.

23. Dimitroff CJ, Kupper TS, Sackstein R. Prevention of leukocyte migration to inflamed skin with a novel fluorosugar modifier of cutaneous lymphocyte-associated antigen. J Clin Invest. 2003; 112:1008-1018. [PubMed: 14523038]

24. Gold H, Munneke S, Dinkelaar J, Overkleeft HS, Aerts JMG, Codée JDC, van der Marel GA. A practical synthesis of capped 4-methylumbelliferyl hyaluronan disaccharides and tetrasaccharides as potential hyaluronidase substrates. Carbohydr Res. 2011; 346:1467-1478. [PubMed: 21536258]

25. Danac R, Ball L, Gurr SJ, Fairbanks AJ. Synthesis of UDP-glucose derivatives modified at the 3$\mathrm{OH}$ as potential chain terminators of $\beta$-glucan biosynthesis. Carbohydr Res. 2008; 343:1012-1022. and references cited therein. [PubMed: 18336802]

26. Muller T, Danac R, Ball L, Gurr SJ, Fairbanks AJ. Synthesis of UDP-GlcNAc derivatives modified at $\mathrm{OH}-4$ as potential chain-terminators of chitin biosynthesis. Tetrahedron Assym. 2007; 18:12991307.

27. Kisilevsky R, Szarek WA, Ancsin JB, Elimova E, Marone S, Bhat S, Berkin A. Inhibition of amyloid A amyloidogenesis in vivo and in tissue culture by 4-deoxy analogues of peracetylated 2acetamido-2-deoxy- $\alpha$ - and $\beta$-d-glucose. Am J Pathol. 2004; 164:2127-2137. and references cited therein. [PubMed: 15161647]

28. Yeager AR, Finney NS. Synthesis of fluorescently labeled UDP-GlcNAc analogues and their evaluation as chitin synthase substrates. J Org Chem. 2005; 70:1269-1275. [PubMed: 15704960]

29. Sharma M, Bernacki RJ, Hillman MJ, Korytnyk W. Fluorinated carbohydrates as potential plasma membrane modifiers. Synthesis of 3-deoxy-3-fluoro derivatives of 2-acetamido-2-deoxy-dhexopyranoses. Carbohydr Res. 1993; 240:85-93. [PubMed: 8458017]

30. Dube DH, Bertozzi CR. Metabolic oligosaccharide engineering as a tool for glycobiology. Curr Opin Chem Biol. 2003; 7:616-625. [PubMed: 14580567]

31. Cai Y, Ling CC, Bundle DR. Facile approach to 2 -acetamido-2-deoxy- $\beta$-d-glucopyranosides via a furanosyl oxazoline. Org Lett. 2005; 7:4021-4024. [PubMed: 16119957]

32. Horton D, Hughes JB, Jewell JS, Philips KD, Turner WN. Anomeric equilibria in derivatives of amino sugars. Nuclear magnetic resonance studies on acetylated amino sugars and specifically deuterated analogs. J Org Chem. 1967; 32:1073-1080. [PubMed: 6042145]

33. Kajihara Y, Kodama H, Endo T, Hashimoto H. Novel features of acceptor recognition by $\beta-(1-4)-$ galactosyltransferase. Carbohydr Res. 1998; 306:361-378.

34. Wang Z, Zhou L, El-Boubbou K, Ye XS, Huang X. Multi-component one-pot synthesis of the tumor-associated carbohydrate antigen Globo-H based on preactivation of thioglycosyl donors. J Org Chem. 2007; 72:6409-6420. [PubMed: 17658849]

35. Hernandez-Torres JM, Liew ST, Achkar J, Wei A. Optimized synthesis of an orthogonally protected glucosamine. Synthesis. 2002:487-490.

36. Ogawa T, Nakabayashi S. Synthetic studies on cell surface glycans. Part XI. Synthesis of 3,6-di-Oacetyl-2-deoxy-2-phthalimido-4-O-(2,3,4,6-tetra-O-acetyl- $\beta$-d-galactopyranosyl)- $\beta$-dglucopyranosyl chloride. Carbohydr Res. 1981; 97:81-86.

37. Barthel SR, Antonopoulos A, Cedeno-Laurent F, Schaffer L, Hernandez G, Patil SA, North SJ, Dell A, Matta KL, Neelamegham S, Haslam SM, Dimitroff CJ. Peracetylated 4-fluoroglucosamine reduces the content and repertoire of $\mathrm{N}$ - and $\mathrm{O}$-glycans without direct incorporation. $\mathrm{J}$ Biol Chem. 2011; 286:21717-21731. [PubMed: 21493714]

38. Mack H, Basabe JV, Brossmer R. 2-Acetamido-2-deoxy-d-gluco- and -d-manno-furanose. A simple preparation of 2-acetamido-2-deoxy-d-mannose. Carbohydr Res. 1988; 175:311-316. [PubMed: 3401881]

39. Knudson W, Knudson CB. Assembly of a chondrocyte-like pericellular matrix on nonchondrogenic cells. Role of the cell surface hyaluronan receptors in the assembly of a pericellular matrix. J Cell Sci. 1991; 99:227-235. [PubMed: 1715873] 
40. Ahmed SA, Gogal RMJ, Walsh JE. A new rapid and simple non-radioactive assay to monitor and determine the proliferation of lymphocytes: an alternative to $[3 \mathrm{H}]$ thymidine incorporation assay. $\mathrm{J}$ Immunol Methods. 1994; 170:211-224. [PubMed: 8157999] 


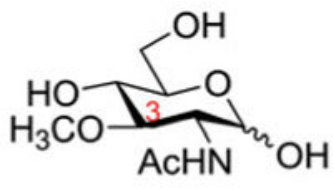

1

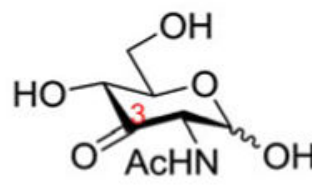

2

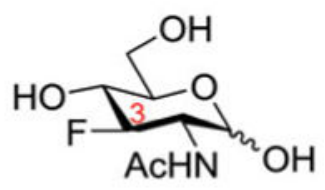

3

Figure 1.

Structures of compounds 1-3 (color figure available online). 


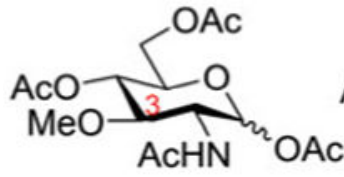

4

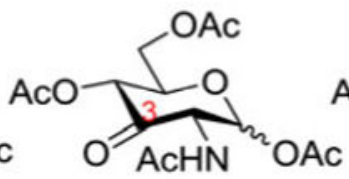

5

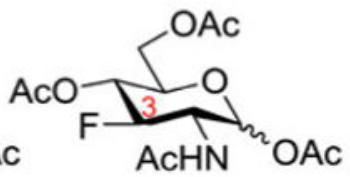

6

Figure 2.

Structures of compounds 4-6 (color figure available online). 

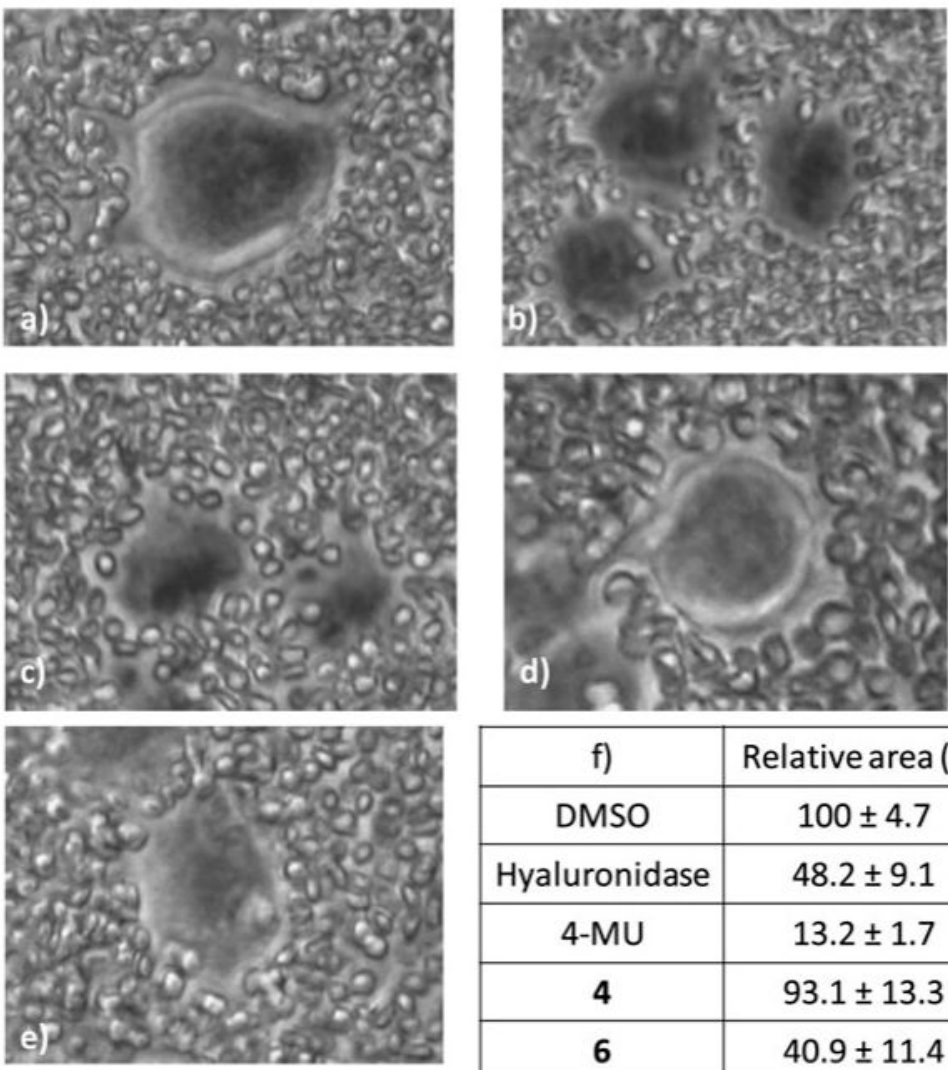

\begin{tabular}{|c|c|}
\hline f) & Relative area (\%) \\
\hline DMSO & $100 \pm 4.7$ \\
\hline Hyaluronidase & $48.2 \pm 9.1$ \\
\hline $4-M U$ & $13.2 \pm 1.7$ \\
\hline $\mathbf{4}$ & $93.1 \pm 13.3$ \\
\hline $\mathbf{6}$ & $40.9 \pm 11.4$ \\
\hline
\end{tabular}

Figure 3.

Effect of various compounds on the formation of a pericellular HA matrix by KP1-NL cells as assessed by a particle exclusion assay. Representative pictures of KP1-NL cells following incubation with (a) DMSO control; (b) Streptomyces hyaluronidase (1.0 U/mL); (c) 4-MU $(100 \mu \mathrm{M})$; (d) GlcNAc analog $4(100 \mu \mathrm{M})$; and (e) GlcNAc analog $6(100 \mu \mathrm{M})$. Fixed sheep erythrocytes (the small cells in the pictures) were then added to the cells to help visualize the pericellular matrix around the cancer cells. The pictures were taken at identical magnification (each picture represents an area of $100 \mu \mathrm{m}$ in width). (f) Quantification of the relative sizes of areas in particle exclusion assay assessed using Image $\mathrm{J}$. 


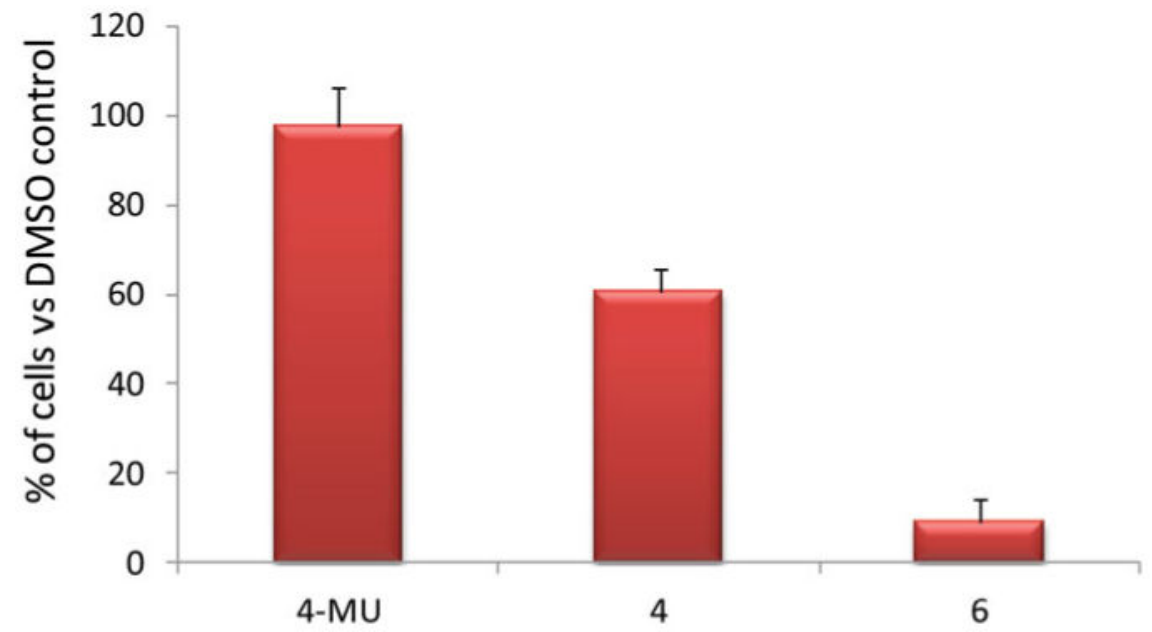

Figure 4.

Number of KP1-NL cells upon incubation with 4-MU, compound 4, and compound $\mathbf{6}$ respectively at $100 \mu \mathrm{M}$ for 72 hours as determined by Alamar blue assay. The number of cells treated with DMSO was set as $100 \%$ (color figure available online). 


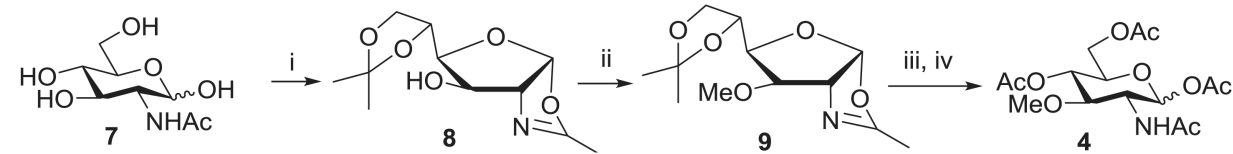

Scheme 1.

Reagents and Conditions: i) Acetone $/ 2$ eq $\mathrm{FeCl}_{3}$, reflux, $60^{\circ} \mathrm{C}, 65 \%$; ii) 2 eq $\mathrm{NaH}, 1.5 \mathrm{eq}$ Mel, DMF, $0^{\circ} \mathrm{C}$ to rt, $96 \%$; iii) 0.4 eq PTSA, THF/ $\mathrm{H}_{2} \mathrm{O} 2: 1$; iv) $\mathrm{Ac}_{2} \mathrm{O} /$ Pyridine, rt, $50 \%$. 
a)

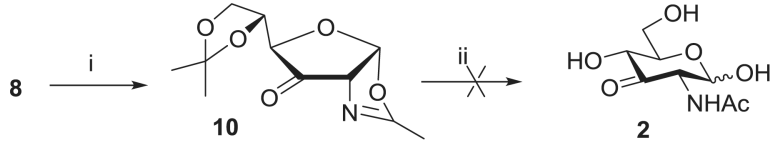

b)

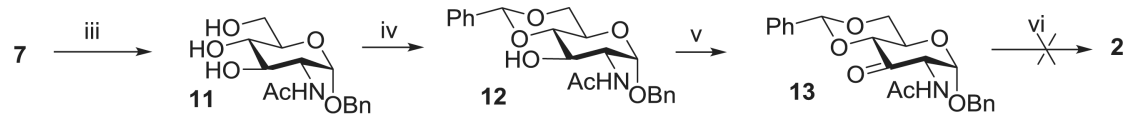

c)
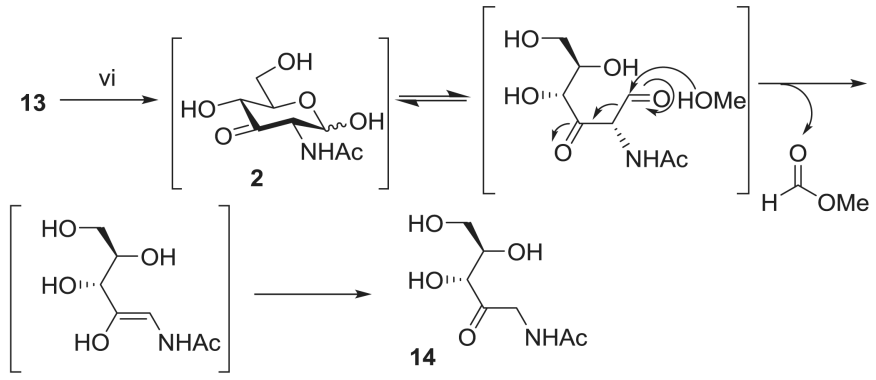

Scheme 2.

Reagents and Conditions: i) 1.4 eq $\mathrm{COCl}_{2}, 2.5$ eq DMSO, 5 eq $\mathrm{Et}_{3} \mathrm{~N},-75^{\circ} \mathrm{C}$ to rt, $92 \%$; ii) 0.4 eq PTSA, THF/ $\mathrm{H}_{2} \mathrm{O} 2: 1$; iii) $\mathrm{BnOH}, \mathrm{HCl}, 90^{\circ} \mathrm{C}, 71 \%$, iv) 5 eq $\mathrm{PhCH}(\mathrm{OMe})_{2}, 0.6$ eq camphorsulfonic acid, DMF, rt, 95\%, v) 1.4 eq $\mathrm{COCl}_{2}, 2.5$ eq DMSO, 5 eq $\mathrm{Et}_{3} \mathrm{~N},-75^{\circ} \mathrm{C}$ to rt, $90 \%$; vi) $\mathrm{H}_{2}, \mathrm{Pd} / \mathrm{C}, \mathrm{MeOH}$. 

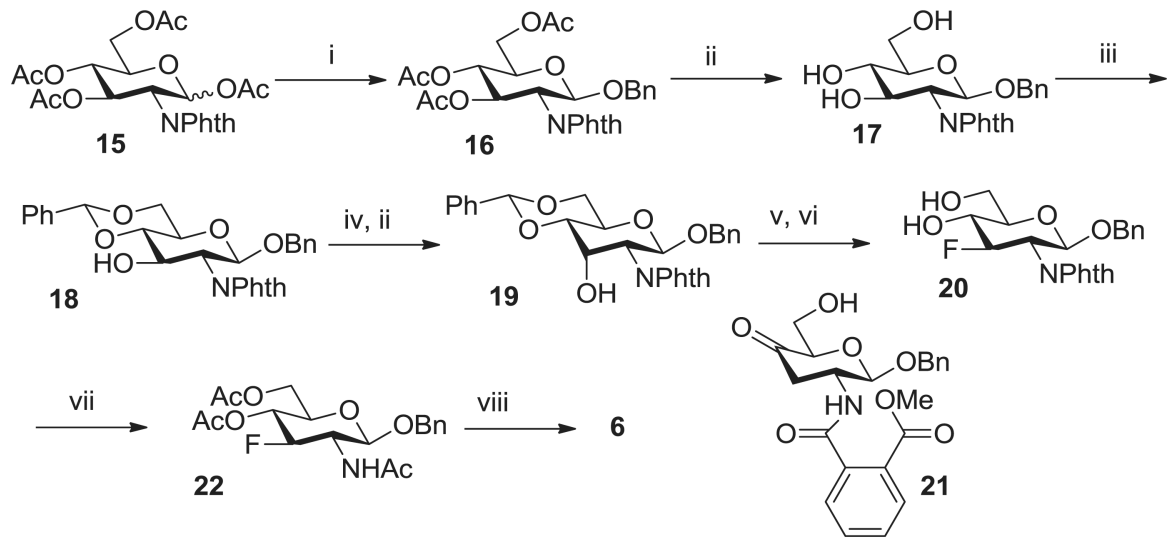

Scheme 3.

Reagents and Conditions: i) 2 eq $\mathrm{BnOH}, 3$ eq $\mathrm{BF}_{3} \mathrm{OEt}_{2}, \mathrm{CH}_{2} \mathrm{Cl}_{2}, 79 \%$; ii) $0.3 \mathrm{M} \mathrm{NaOMe}$, $\mathrm{MeOH} / \mathrm{CH}_{2} \mathrm{Cl}_{2},-10^{\circ} \mathrm{C}$; iii) $\mathrm{PhCH}(\mathrm{OMe})_{2}, 0.08$ eq camphorsulfonic acid, $\mathrm{CH}_{3} \mathrm{CN}, 77 \%$; iv) 2 eq $\mathrm{Tf}_{2} \mathrm{O}, 5$ eq pyridine, $-20^{\circ} \mathrm{C}$ to $10^{\circ} \mathrm{C} ; 6$ eq tetrabutylammonium acetate, toluene, $60^{\circ} \mathrm{C}$ $\%$; v) 6 eq DAST, $\mathrm{CH}_{2} \mathrm{Cl}_{2},-5^{\circ} \mathrm{C}$ to rt; vi) 6 eq $\mathrm{AcCl}, \mathrm{MeOH} / \mathrm{CH}_{2} \mathrm{Cl}_{2}, 28 \%$ yield from $\mathbf{1 8}$; vii) $\mathrm{H}_{2} \mathrm{~N}\left(\mathrm{CH}_{2}\right)_{2} \mathrm{NH}_{2}, \mathrm{nBuOH}, 90^{\circ} \mathrm{C}$; acetic anhydride, pyridine rt, $80 \%$; viii) $\mathrm{H}_{2}, \mathrm{Pd} / \mathrm{C}$, $\mathrm{MeOH}$; acetic anhydride, pyridine, $\mathrm{rt}, 60 \%$. 


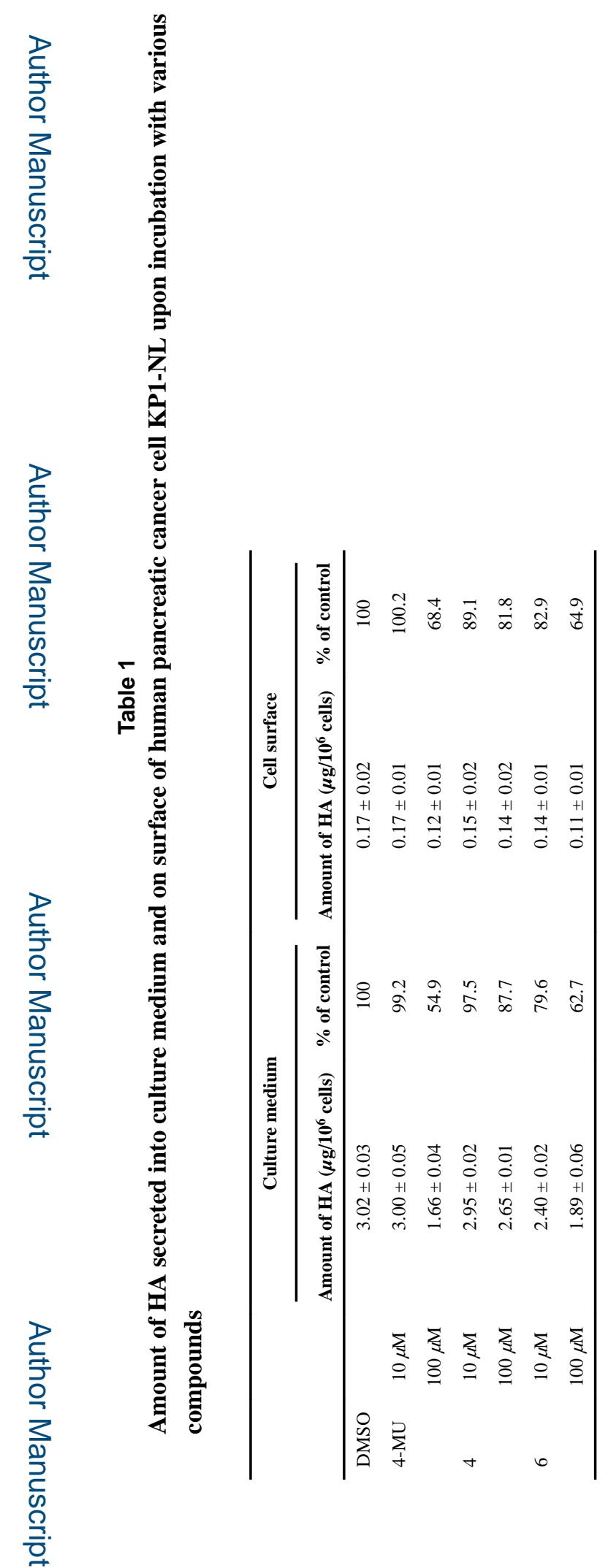

J Carbohydr Chem. Author manuscript; available in PMC 2016 April 18. 